\title{
PARTISIPASI MASYARAKAT DALAM MEWUJUDKAN KUNINGAN SEBAGAI KABUPATEN KONSERVASI (Studi di Kabupaten Kuningan)*
}

\author{
Suwari Akhmaddhian dan Anthon Fathanudien \\ Fakultas Hukum Universitas Kuningan \\ Email : suwariakhmaddhian@gmail.com
}

\begin{abstract}
Public Participation in realizing Kuningan as a research location Conservation District is performed in Kuningan District. The purpose of this study was to determine the Implementation Regulations Kuningan District No. 12 of 2007 on the Conservation of Water Resources. and to find out what people's participation in realizing Kuningan as Conservation District. This research can be useful, among others, the study has been practically is can be used in policy-making related to the environment and settings to improve community participation in supporting the preservation of the environment and conservation, especially in the District Kuningan and generally in Indonesia. The method used by the researchers in this study is a discussion of evaluative method of analysis, which is a method of collecting and presenting data obtained to analyze the actual situation and then performed a rational analysis based reference juridical through library research and field research. The results of research that community participation in realizing the Kuningan as a conservation district is a step forward because it participates in government programs to help the protection and preservation of the environment that will create a beautiful and healthy environment. Forms of community participation brass districts namely through bridal care environment (pepeling), students are concerned about the environment (seruling) and officials concerned.about.the.environment (apel).
\end{abstract}

Keywords: Participation, Community, Conservation, Environment

\section{Pendahuluan}

Lingkungan merupakan isu yang sedang berkembang di dunia bersamaan dengan Hak Asasi Manusia dan Korupsi. Pelestarian alam di Indonesia secara hukum mengacu kepada 2 (dua) Peraturan induk, yakni Undang-Undang Nomor 05 Tahun 1990 tentang Konservasi Sumberdaya Alam Hayati dan Ekosistemnya; serta Undang-Undang Nomor 41 Tahun 1999 tentang Kehutanan. Undang-Undang Nomor 05 Tahun 1990 tentang Konservasi Sumberdaya Alam Hayati dan Ekosistemnya bertitik berat pada pelestarian keanekaragaman hayati, baik keanekaragaman hayati hutan maupun bukan;

- Artikel ini merupakan hasil Hibah Penelitian Dosen Pemula Dikti 2014, Sumber dana dari Dikti dengan No.2007/K4/KM/2014, tanggal 2 Juni 2014 
baik di dalam kawasan hutan negara maupun di luarnya. Sedangkan UndangUndang Nomor 41 Tahun 1999 tentang Kehutanan salah satunya mengatur konservasi alam di kawasan hutan negara; namun bukan hanya mencakup konservasi keanekaragaman hayati, melainkan meliputi pula perlindungan fungsi-fungsi penunjang kehidupan yang disediakan kawasan hutan. UndangUndang Nomor 41 Tahun 1999 tentang Kehutanan membedakan dua kategori besar kawasan hutan yang dilindungi, yakni: pertama Hutan lindung, yakni kawasan hutan negara yang mempunyai fungsi pokok sebagai perlindungan sistem penyangga kehidupan untuk mengatur tata air, mencegah banjir, mengendalikan erosi, mencegah instrusi air laut, dan memelihara kesuburan tanah; dan kedua Hutan konservasi, yakni kawasan hutan negara dengan ciri khas tertentu, yang mempunyai fungsi pokok pengawetan keanekaragaman tumbuhan dan satwa serta ekosistemnya. Selanjutnya, Undang-Undang Nomor 41 Tahun 1999 tentang Kehutanan lebih lanjut merinci kawasan hutan konservasi ke dalam 3 (tiga) kawasan yaitu: Pertama Kawasan hutan suaka alam. Ialah kawasan hutan negara dengan ciri khas tertentu, yang mempunyai fungsi pokok sebagai kawasan pengawetan keanekaragaman tumbuhan dan satwa serta ekosistemnya, yang juga berfungsi sebagai wilayah sistem penyangga kehidupan. Kedua Kawasan hutan pelestarian alam. lalah kawasan hutan negara dengan ciri khas tertentu, yang mempunyai fungsi pokok perlindungan sistem penyangga kehidupan, pengawetan keanekaragaman jenis tumbuhan dan satwa, serta pemanfaatan secara lestari sumber daya alam hayati dan ekosistemnya. Ketiga Taman buru yakni kawasan hutan negara yang ditetapkan sebagai tempat wisata berburu.

Kabupaten Kuningan merupakan daerah pertanian berlokasi di kaki Gunung Ciremai dan memiliki sumber air melimpah, termasuk air tawar 620 mata air dan 43 sungai kecil dengan debit air total 8.352 liter / detik, dan karena itu penuh potensial agribisnis dan investasi dalam air berbasis perusahaan. Kabupaten Kuningan, adalah sebuah kabupaten di Provinsi 
Jawa Barat, Indonesia. Ibukotanya adalah Kuningan. Letak astronomis kabupaten ini di antara $108^{\circ} 23^{\prime \prime}-108^{\circ} 47^{\prime \prime}$ Bujur Timur dan $6^{\circ} 45^{\prime \prime}-7^{\circ} 13^{\prime \prime}$ Lintang Selatan. Kabupaten ini terletak di bagian timur Jawa Barat, berbatasan dengan Kabupaten Cirebon di utara, Kabupaten Brebes (Jawa Tengah) di timur, Kabupaten Ciamis di selatan, serta Kabupaten Majalengka di barat. Kabupaten Kuningan terdiri atas 32 kecamatan, yang dibagi lagi atas sejumlah 361 desa dan 15 kelurahan. Pusat pemerintahan di Kecamatan Kuningan. Bagian timur wilayah kabupaten ini adalah dataran rendah, sedang di bagian barat berupa pegunungan, dengan puncaknya Gunung Ceremai (3.076 m) yang biasa salah kaprah disebut dengan Gunung Ciremai, gunung ini berada di perbatasan dengan Kabupaten Majalengka. Gunung Ceremai adalah gunung tertinggi di Jawa Barat. Mempunyai luas daerah yaitu 1.178,58 $\mathrm{km}^{2}$ dan Menurut hasil Suseda Jabar tahun 2010, penduduk Kab.Kuningan yang tersebar di 379 desa/kelurahan meliputi 32 kecamatan itu, seluruhnya tercatat 1.873 .528 jiwa.

Permasalahan utama dalam lingkungan hidup yang teridentifikasi ada 5 (lima) antara lain ${ }^{1}: 1$ ) kerusakan lahan akibat penggundulan hutan, penebangan liar, alih fungsi lahan untuk perkebunan dan tanaman industri, penambangan minyak, industri dan permukiman; 2) abrasi pinggir sungai akibat laluintas pelayaran kapal-kapal besar dan cepat; 3) pendangkalan sungai oleh tingginya erosi, abrasi dan sedimentasi; 4) gangguan pola aliran air permukaan akibat alih fungsi lahan, keberadaan pelabuhan, dermaga, dan logpond; 5) penurunan kualitas air akibat buangan limbah cair industri, domestik pembuangan air ballast kapal, dan buangan limbah padat domestik. Kabupaten kuningan pada tahun 2006 telah mendeklarasikan sebagai kabupaten konservasi dan pada tahun 2007 terbit Peraturan Daerah Kabupaten Kuningan Nomor 12 Tahun 2007 tentang Konservasi Sumber Daya Air, oleh karena itu untuk mewujudkan kuningan

\footnotetext{
${ }^{1}$ Nana Sudiana dan Hasmana Soewandita, 2007, Pola Konservasi Sumber Daya Air di Daerah Aliran Sungai Siak, Jurnal Alami Vol. 12 Nomor 1, Halaman. 44-51.
} 
sebagai kabupaten konservasi di perlukan peran dan partisipasi serta dukungan semua pihak yang terkait baik pemerintah daerah ataupun masyarakat kabupaten kuningan. Maka dengan adanya penelitian ini diharapkan dapat mengukur dan mengetahui sejauh mana partisipasi masyarakat kabupaten kuningan dalam mendukung kuningan sebagai kabupaten konservasi sesuai dengan harapan dan diharapkan hasil penelitian ini dijadikan landasan dan acuan dari pihak terkait dalam membuat atau memperbaiki kebijakan yang terkait konservasi di kabupaten kuningan.

\section{Perumusan Masalah}

Masalah lingkungan hidup ini dapat ditinjau dari aspek medik, planologis teknologis, teknik lingkungan, ekonomi dan hukum. Hal ini dikemukakan oleh Siti Sundari Rangkuti yaitu Segi-segi hukum pengelolaan lingkungan hidup dan konservasi sumber daya alam di Indonesia perlu dikaji secara intensif, karena pengelolaan lingkungan tidak mungkin tanpa pengaturan hukum. Hal ini tidak berarti bahwa ahli hukum dapat menangani masalah lingkungan terlepas dari disiplin ilmu lain yang berkaitan dengan bidang lingkungan hidup ${ }^{2}$. Berdasarkan hal tersebut maka penulis tertarik untuk menulis penelitian dengan judul "Partisipasi Masyarakat dalam mewujudkan Kuningan sebagai Kabupaten Konservasi.". Adapun yang menjadi pokok permasalahan yang akan menjadi fokus perhatian utama yang akan dibahas dalam penelitian ini dapat di uraikan dalam pertanyaan diantaranya adalah sebagai berikut:

1. Bagaimana Implementasi Peraturan Daerah Kabupaten Kuningan Nomor 12 Tahun 2007 tentang Konservasi Sumber Daya Air.?

2. Apa Partisipasi Masyarakat dalam mewujudkan Kuningan sebagai Kabupaten Konservasi.?

\footnotetext{
${ }^{2}$ Siti Kotijah, 2010, Implementasi Prinsip-prinsip Kehutanan dalam Rangka Konservasi Kehutanan: studi kasus di Jawa Timur, Jurnal Magister Hukum, Vol. 1 Nomor 2, Surabaya : Program Studi Magister Ilmu Hukum, Universitas Wisnuwardhana, Halaman. 354-386
} 


\section{Metode Penelitian}

Metode penelitian yang digunakan oleh penyusun dalam pembahasan penelitian ini adalah metode evaluatif analisis, yaitu suatu metode mengumpulkan dan menyajikan data yang diperoleh untuk menganalisis keadaan yang sebenarnya dan selanjutnya dilakukan analisa rasional berdasarkan acuan yuridis melalui penelitian kepustakaan dan penelitian lapangan. Metode penelitian hukum, menurut Soerjono Soekanto adalah “ suatu kegiatan ilmiah, yang di dasarkan pada metode, sistematika dan pemikiran tertentu, yang bertujuan mempelajari satu atau beberapa gejala hukum tertentu, dengan menganalisanya. ${ }^{3}$

1. Data dan Sumbernya

a. Data primer atau data empiris yaitu sumber data dari melakukan observasi dan data berupa keterangan-keterangan dari nara sumber, antara lain pengusaha, pengurus LSM, masyarakat, akademisi dan praktisi hukum.

b. Data sekunder yang digunakan dalam penelitian ini, Penggunaan data sekunder ini karena memiliki beberapa keuntungan, yaitu ${ }^{4}$ :

1) Pada umumnya data sekunder dalam keadaan siap terbuat dan dapat dipergunakan dengan segera.

2) Baik bentuk maupun isi data sekunder, telah di bentuk dan disini oleh peneliti-peneliti terdahulu, sehigga peneliti kemudian, tidak mempunyai pengawasan terhadap pengumpulan, pengolahan, analisa, maupun konstruksi data.

3) Tidak terbatas oleh waktu maupun tempat.

Data sekunder, biasanya dibedakan menjadi tiga kategori, yaitu bahan hukum primer, bahan hukum sekunder dan bahan hukum tersier.

\footnotetext{
${ }^{3}$ Soerjono Soekanto, Pengantar Penelitian Hukum.cet.2007, Jakarta : UI Press, 1984, hlm.5

${ }^{4}$ Op.Cit, hlm.12.
} 
1. Bahan hukum primer, yaitu berupa ketentuan perundang-undangan yang mengikat. Adapun bahan hukum primer dalam penyusunan penelitian ini adalah

2. Bahan hukum sekunder, yaitu bahan-bahan yang menjelaskan bahan hukum primer, seperti hasil-hasil penelitian, teori , konsep pemikiran para ahli atau buku-buku yang berkorelasi dengan masalah yang di teliti. Dalam penyusunan penelitian ini, bahan hukum sekundernya, adalah buku-buku yang berkaitan langsung dengan masalah yang dikaji ,pendapat para ahli, teori-teori yang terkait dengan masalah yang diteliti, serta putusan-putusan pengadilan tentang kasus lingkungan yang telah terjadi dalam masyarakat

3. Bahan hukum tersier, yaitu bahan yang menjelaskan bahan hukum primer dan sekunder sepertinya kamus hukum atau kamus umum.

2. Alat Pengumpul Data

a Studi Kepustakaan Yaitu mencari dan menggunakan sumber dari datadata primer berupa peraturan perundang-undangan, buku-buku, internet, artikel, diktat kuliah dan tulisan lain yang ada hubungannya dengan materi penulisan hukum.

b Studi Lapangan Yaitu melakukan observasi ke intansi yang menjadi objek penelitian yaitu Badan Pengelola Lingkungan Hidup Daerah, BAPEDA serta melakukan wawancara dengan masyarakat, pengurus LSM, akademisi dan praktisi hukum.

3. Teknik Penelitian yang digunakan dalam penelitian ini adalah :

a Teknik Observasi yaitu dengan jalan mencari responden dan mengamatinya

b Tenik Angket yaitu teknik yang berisi sejumlah pertanyaan untuk mengetahui informasi partisipasi masyarakat dalam konservasi lingkungan yang berdasarkan letak geografis dan latar belakang responden. 
c Teknik Wawancara yaitu dengan menggunakan tanya jawab langsung dengan terlebih dahulu menyiapkan hal-hal yang perlu ditanyakan yang berkaitan dengan data-data konservasi lingkungan yang di dapat.

4. Pengolahan dan Analisis Data.

Setelah data terhimpun melalui observasi, angket dan wawancara, maka dilakukan penolahan dan analis data secara kualitatif. Sesuai dengan sifat penelitian ini, yaitu Evaluatif Analisis.

Suatu penelitian membutuhkan kerangka berpikir untuk menjawab permasalahan-permasalahan yang telah di rumuskan. Kerangka berfikir yang dikenal dalam penelitian hukum terdiri dari atas kerangka teoritis dan kerangka konseptual. 'kerangka teoritis merupakan kerangka dimana masalah di ambil atau di hubungkan'5. Pada umumnya kerangka teoritis disajikan dalam bentuk proposisi atau pernyataan yang salung berkaitan dan bertujuan memberikan gambaran yang sistematis tentang suatu gejala dan selanjutnya dapat membantu kasusu-kasus konkrit yang lebih adil, teori dalam penelitian mempunyai fungsi untuk mengarahkan kepada peneliti apa yang harus dilakukan. Kerangka konseptual adalah kerangka yang lebih menggambarkan hubungan antara konsep-konsep khusus yang melandasi penelitian. Kerangka konseptual lebih mengedapankan definisi-definisi dari suatu permasalahan dengan kata lain konsep merupakan urian-uraian mengenai hubungan-hubungan dalam fakta tersebut ${ }^{6}$.

\section{Pembahasan}

Implementasi Peraturan Daerah Kabupaten Kuningan Nomor 12 Tahun 2007 tentang Konservasi Sumber Daya Air.

Kabupaten kuningan pada tahun 2006 telah mendeklarasikan sebagai kabupaten konservasi dan pada tahun 2007 terbit Peraturan Daerah

\footnotetext{
${ }^{5}$ Soerjono Soekanto, Ringkasan metode Penelitian Hukum Empiris, Jakarta:Ind-Hill 1990, hlm 110.

${ }^{6}$ Soerjono Soekanto, Pengantar Penelitian Hukum.cet.2007, Jakarta : UI Press, 1984, hlm.132.
} 
Kabupaten Kuningan Nomor 12 Tahun 2007 tentang Konservasi Sumber Daya Air, oleh karena itu untuk mewujudkan kuningan sebagai kabupaten konservasi di perlukan peran dan partisipasi serta dukungan semua pihak yang terkait baik pemerintah daerah ataupun masyarakat kabupaten kuningan. Maka dengan adanya penelitian ini diharapkan dapat mengukur dan mengetahui sejauh mana peran pemerintah daerah kabupaten kuningan dalam mendukung kuningan sebagai kabupaten konservasi sesuai dengan harapan dan diharapkan hasil penelitian ini dijadikan landasan dan acuan dari pihak terkait dalam membuat atau memperbaiki kebijakan yang terkait konservasi di kabupaten kuningan. Mengatasi tantangan konservasi sumberdaya air di perlukan komitmen politik yang kuat dari pemerintah untuk melakukan kebijakan pengelolaan sumberdauya air yang holistik termasuk mengantisipasi tantangan konservasi pada saat pengusahaan air bersih yang dilakukan oleh koporasi privat ${ }^{7}$.

Pemerintah Daerah mempunyai peran yang sangat strategis yaitu dalam memberikan pengetahuan dan upaya peningkatan pengertian konservasi air dan penerapannya di seluruh lapisan masyarakat dapat dikelompokkan dalam 3 (tiga) ${ }^{8}$ kelompok sasaran yakni :

1. Politisi dan Pembuat Kebijakan mereka perlu memahami bagaimana kepedulian konservasi air dapat membantu memecahkan masalah kekurangan air sekaligus memberikan manfaat sosial-ekonomi dan lingkungan. Para politisi dan pembuat kebijakan mempunyai peran penting sebagai katalis antara pakar- pakar teknik dan masyarakat umum. Selain itu, yang lebih panting adalah mereka dapat menjadi perantara untuk menjalin kemitraan antar departemen yang diperlukan untuk mengembangkan konservasi air secara efektif.

\footnotetext{
${ }^{7}$ Budi Widianarko, Privatisasi dan Tantangan Konservasi Sumber Daya Air, Jurnal Renai edisi Air : Hak Asasi Versus Komodifikasi, Pustaka Percik, 2005, Halaman. 49 -57

${ }^{8}$ Anik Sarminingsih, Kajian Upaya Konservasi Sumberdaya Air dalam Peningkatan Kesadaran Masyarakat, Jurnal PRESIPITASI Vol. 5 No.2 September 2008, Halaman 42-48
} 
2. Pengelola dan Peran Pakar Air yang terlibat dalam perencanaan, pengembangan, dan pengelolaan tata air, termasuk pengelola dan ilmuwan yang bekerja untuk pelestarian lingkungan hidup. Maksud kajian ini adalah menunjukkan betapa pentingnya teknik konservasi per1u dimasukkan ke dalam perencanaan rinci dan pembangunan sistem suplai air bersih. Selain itu, kajian ini juga dimaksudkan untuk menunjukkan bahwa teknik-teknik sosialisasi (social marketing) dapat dipakai untuk meningkatkan kesadaran tentang per1unya mengelola kebutuhan air.

3. Media Massa dan Pendidik, pengetahuan mereka tentang sektor pengairan mungkin hanya sedikit tetapi mereka ahli dalam kehumasan, komunikasi, pemasaran, dan pendidikan. Langkah ini menjelaskan kepada mereka bagaimana keahlian yang beragam tersebut dapat mendukung tercapainya kepedulian konservasi air di masyarakat.

Konservasi sumber daya air memerlukan aturan dalam yang mengikat semua pihak terutama dalam hal pembagian tata ruang dan wilayah sehingga mempermudah dalam menyiapkan daerah-derah mana yang menjadi konservasi maka di perlukanp penyusunan dan penetapan RTRW dilaksanankan menuruti langkah-langkah sebagai berikut ${ }^{9}: 1$ ). Menentukan arah pengembangan, yang akan dicapai dilihat dari segi ekonomi, sosial, budaya, daya dukung dan daya tampung lingkungan, serta fungsi pertahanan keamanan; 2).Mengidentifikasi berbagai potensi dan masalah pembangunan dalam suatu wilayah perencanaan; 3).Perumusan perencanaan tata ruang; 4). Penetapan rencana tata ruang.

Dalam penanganan masalah-masalah lingkungan, penanganan hukum preventif melalui sarana hukum administrasi menduduki posisi penting, karena fungsinya yang bertolak dari asas penanggulangan pada sumber (abatement at the source principle). Sehingga proses penegakan hukum

${ }^{9}$ Sutedjo, Keterpaduan kebijakan lingkungan dan tata ruang, Jurnal Yustisia Edisi Nomor 72 Sept-Des 2007, Surakarta : Fakultas Hukum Universitas Sebelas Maret, Halaman. 15 - 26. 
melalui sarana hukum administrasi dianggap lebih memenuhi fungsi perlindungan " hak atas lingkungan hidup yang baik dan sehat" sebagai hak konstitusional. ${ }^{10}$ Upaya lain sebagai jalan alternatif dalam menunjang konservasi yang dimaksud adalah ${ }^{11}: 1$ ).Penetapan/pemilikan jenis tanaman perkebunan sesuai ketinggian wilayah (hilir, dataran rendah/tinggi dan hulu); 2).Perilaku penambangan galian (pada badan sungai yang tidak terawasi); 3).Penertiban pengawasan pengurasan air bawah tanah (ABT); 4). Upaya-upaya lain dalam menjaga kelestarian/keutuhan kulit bumi. Kondisi ini mengidentifikasikan telah terjadi konversi lahan dari peruntukannya karena bertambahnya jumlah dan aktivitas ekonomi penduduk jawa barat Penyimpangan pemanfaatan lahan paling banyak terjadi pada areal hutan lindung, yakni angkanya mencapai 17,14 \% dan kawasan budidaya sebesar $17,78 \%$. Angka-angka pergeseran penggunaan lahan tersebut adalah sebagai berikut $^{12}$ :

1. Hutan berkurang sebesar 123.624 ha

2. Tanah kosong berkurang seluas $96.564,96$ ha

3. Sawah berkurang $337.057,92$ ha

4. Perkebunan berkurang seluas $162.033,12$ ha

Berdasarkan uraian diatas untuk mencapai tujuan konservasi di kabupaten kuningan maka pemerintah daerah kabupaten kuningan melakukan upaya-upaya dalam hal kebijakan yaitu dengan membuat peraturan-peraturan yang berkaitan dan mendukung konservasi ${ }^{13}$ yaitu :

${ }^{10}$ Kartono, Penegakan hukum lingkungan administratif dalam undang-undang perlindungan dan pengelolaan lingkungan hidup, Jurnal Dinamika Hukum, Vol.9 No. 3 September 2009, Purwokerto : FH Unsoed, Halaman. 247-257.

${ }^{11}$ Karolina Sitepu, Beberapa Alternatif mendukung Konservasi Hutan dan Air serta Kelangsungan Hidup, Jurnal Ilmiah Abdi Ilmu, Vol.1 Nomor 1 September 2008, Halaman. 26-33

${ }^{12}$ Benny Warsilah, Peran Sumber Daya Sosial dalam Mendukung Konservasi Sumber Daya Air di Jabodetabekpunjur, Jurnal Komunika Vol.10 Nomor 2 Tahun 2007, halaman. 45-59.

13 Suwari Akhmaddhian, "Peran Pemerintah Daerah dalam Mewujudkan Hutan Konservasi Berdasarkan Undang-Undang Nomor 41 Tahun 1999 Tentang Kehutanan (Studi di Kabupaten Kuningan)." Jurnal Dinamika Hukum Vol. 13,Nno. 3 September 2013, , Purwokerto : FH Unsoed, Halaman. 464-478. 
1. Peraturan Daerah Kabupaten Kuningan Nomor 12 Tahun 2007 tentang Konservasi Sumber Daya Air.

2. Peraturan Daerah Kabupaten Kuningan Nomor 13 Tahun 2007 tentang Irigasi.

3. Peraturan Daerah Kabupaten Kuningan Nomor 10 Tahun 2009 tentang Pelestarian Satwa Burung dan Ikan.

4. Peraturan Daerah Kabupaten Kuningan Nomor 15 Tahun 2009 tentang Penngelolaan Air.

5. Peraturan Daerah Kabupaten Kuningan Nomor 12 Tahun 2011 tentang Penyelenggaraan Kebun Raya Kuningan.

6. Peraturan Daerah Kabupaten Kuningan Nomor 13 Tahun 2011 tentang Penatausahaan Hasil Hutan.

7. Peraturan Daerah Kabupaten Kuningan Nomor 26 Tahun 2011 tentang Rencana Tata Ruang Wilayah Kabupaten Kuningan 2011-2031.

8. Surat Keputusan Bupati Kuningan No.522/Kep.01-HUTBUN/2006 tentang Penetapan Tanaman Endemik dan Langka Lokal Kabupaten Kuningan

Selain membuat kebijakan-kebijakan yang berkaitan dengan lingkungan kabupaten kuningan juga meningkatkan status Hutan Lindung Gunung Cermai menjadi Taman Nasional Gunung Cermai, membuat Hutan Kota dan membuat Waduk atau Embung di berbagai wilayah, adapun rinciannya sebagai berikut :

1. Taman Nasional Gunung Cermai (TNGC) seluas 8.935 ha

2. Kebun Raya Kuningan di Kecamatan Pasawahan seluas 154,90 ha

3. Hutan Kota tersebar di 17 Lokasi (12 Kecamatan) seluas 71,5 ha

4. Taman Wisata Alam Linggarjati seluas 15 ha

5. Waduk/Situ/Embung di 114 Lokasi

6. Taman Kota terdiri dari 3 lokasi yang terletak di pusat kota sebagai sarana interaksi masyarakat dengan warga lainnya. 


\section{Partisipasi Masyarakat dalam mewujudkan Kuningan sebagai Kabupaten Konservasi.}

\section{Pengertian Masyarakat}

Definisi Masyarakat menurut Kamus Besar Bahasa Indonesia (KBBI) berarti "sejumlah manusia dalam arti seluas-luasnya dan terikat oleh suatu kebudayaan yg mereka anggap sama" sedangkan menurut Paul B Horton dan C. Hunt masyarakat merupakan kumpulan manusia yang relatif mandiri, hidup bersama-sama dalam waktu yang cukup lama, tinggal di suatu wilayah tertentu, mempunyai kebudayaan sama serta melakukan sebagian besar kegiatan di dalam kelompok / kumpulan manusia tersebut. Masyarakat (yang diterjemahkan dari istilah society) adalah sekelompok orang yang membentuk sebuah sistem semi tertutup atau sebaliknya, dimana kebanyakan interaksi adalah antara individu-individu yang terdapat dalam kelompok tersebut. Kata "masyarakat" berakar dari bahasa Arab, musyarakah. Arti yang lebih luasnya, sebuah masyarakat adalah suatu jaringan hubungan-hubungan antar entitas-entitas. Masyarakat adalah sebuah kelompok atau komunitas yang interdependen atau individu yang saling bergantung antara yang satu dengan lainnya. Pada umumnya sebutan masyarakat dipakai untuk mengacu sekelompok individu yang hidup bersama dalam satu komunitas yang teratur. Syaikh Taqyuddin An-Nabhani seorang pakar sosiologi menjabarkan tentang definisi masyarakat, "sekelompok manusia bisa disebut sebagai suatu masyarakat apabila mempunyai pemikiran, perasaan, serta sistem atau aturan yang sama". Dengan kesamaan itu, manusia lalu berhubungan saling berinteraksi antara sesama mereka berdasarkan kepentingan bersama. Masyarakat sering dikelompokkan berdasarkan cara utamanya dalam mencari penghasilan atau kebutuhan hidup. Beberapa ahli ilmu sosial mengelompokkan masyarakat sebagai: masyarakat pastoral nomadis, masyarakat pemburu, masyarakat bercocoktanam, dan masyarakat agrikultural intensif disebut juga sebagai 
masyarakat peradaban. Faktor-faktor yang mendorong manusia untuk hidup ${ }^{14}$ adalah :

1. Hasrat sosial Adalah merupakan hasrat yang ada pada setiap individu untuk menghubungkan dirinya kepada individu lain atau kelompok

2. Hasrat untuk mempertahankan diri Adalah hasrat untuk mempertahan kan diri dari berbagai pengaruh luar yang mungkin datang kepada nya, sehingga individu tersebut Faktor-faktor yang mendorong manusia untuk hidup bermasyarakat perlu bergabung dangan individu lain atau kelompok.

3. Hasrat berjuang Hasrat ini dapat kita lihat pada adanya persaingan, keingina membantah pendapat orang lain. Sehingga mereka mengadakan persatuan untuk mencapai tajuan, yaitu tujuan bersama.

4. Hasrat harga diri adalah Rasa harga diri merupakan hasrat pada seseorang untuk menganggap atau bertindak atas diri nya lebih tinggi dari pada orang lain, karena mereka ingin mendapat penghargaan yang selayaknya.

5. Hasrat meniru Adalah hasrat untuk menyatakan secara diam-diam atau terang-terangan sebagian dari salah satu gajala atau tindakan.

6. Hasrat bergaul Hasrat untuk bergabung dengan orang-orang tertentu, kelompok tertentu, atau masyarakat tertentu dalam suatu masyarakat.

7. Hasrat untuk mendapat kan kebebasan adalah Hasrat ini tampak jelas pada tindakan-tindakan manusia bila mendapat kekangan-kekagan atau pembatasan-pembatasan.

8. Hasrat untuk memberitahukan adalah Hasrat untuk menyampaikan perasaan-perasaan kepada orang lain biasanya disampaikan dengan suara atau isyarat

9. Hasrat simpati adalah Kesanggupan untuk dengan langsung turut merasakan apa yang dirasakan oleh orang lain.

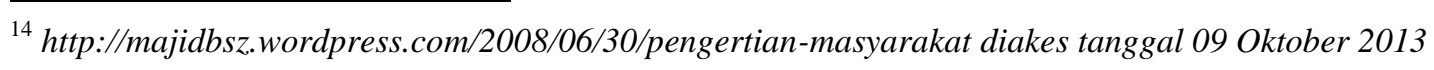




\section{Pengertian Partisipasi}

Definisi Partisipasi menurut Kamus Besar Bahasa Indonesia (KKBI) berarti, (1). Prihal turut berperan serta dalam suatu kegiatan; (2). Keikusertaan; dan (3) peran serta. Dengan demikian, berpartsipasi mengandung arti bahwa: (1) melakukan partisipasi; (2). Berperan serta (dalam suatu kegiatan); dan (3) ikut serta. Sebagai contoh kalimat yang didalamnya memuat kata "partisipasi" adalah: seluruh masyarakat harus berpartisipasi dalam menyukseskan pembangunan. Pengertian dan Prinsip Partisipasi Masyarakat Menurut Ach. Wazir Ws., et al. ${ }^{15}$ partisipasi bisa diartikan sebagai keterlibatan seseorang secara sadar ke dalam interaksi sosial dalam situasi tertentu. Dengan pengertian itu, seseorang bisa berpartisipasi bila ia menemukan dirinya dengan atau dalam kelompok, melalui berbagai proses berbagi dengan orang lain dalam hal nilai, tradisi, perasaan, kesetiaan, kepatuhan dan tanggungjawab bersama. Partisipasi masyarakat menurut Isbandi ${ }^{16}$ adalah keikutsertaan masyarakat dalam proses pengidentifikasian masalah dan potensi yang ada di masyarakat, pemilihan dan pengambilan keputusan tentang alternatif solusi untuk menangani masalah, pelaksanaan upaya mengatasi masalah, dan keterlibatan masyarakat dalam proses mengevaluasi perubahan yang terjadi.

Sedangkan menurut Holil unsur-unsur dasar partisipasi sosial yang juga dapat mempengaruhi partisipasi masyarakat ${ }^{17}$ adalah:1).Kepercayaan diri masyarakat; 2).Solidaritas dan integritas sosial masyarakat; 3).Tanggungjawab sosial dan komitmen masyarakat; 4).Kemauan dan kemampuan untuk mengubah atau memperbaiki keadaan dan membangun

\footnotetext{
${ }^{15}$ Ach. Wazir Ws., et al., ed. 1999. Panduan Penguatan Menejemen Lembaga Swadaya Masyarakat. Jakarta: Sekretariat Bina Desa dengan dukungan AusAID melalui Indonesia HIV/AIDS and STD Prevention and Care Project. Halaman 29.

${ }^{16}$ Isbandi Rukminto Adi. 2007. Perencanaan Partisipatoris Berbasis Aset Komunitas: dari Pemikiran Menuju Penerapan. Depok: FISIP UI Press. Halaman 27

${ }^{17}$ Holil Soelaiman. 1980. Partisipasi Sosial dalam Usaha Kesejahteraan Sosial. Bandung. Halaman 52
} 
atas kekuatan sendiri; 5).Prakarsa masyarakat atau prakarsa perseorangan yang diterima dan diakui sebagai/menjadi milik masyarakat; 6).Kepentingan umum murni, setidak-tidaknya umum dalam lingkungan masyarakat yang bersangkutan, dalam pengertian bukan kepentingan umum yang semu karena penunggangan oleh kepentingan perseorangan atau sebagian kecil dari masyarakat; 7).Organisasi, keputusan rasional dan efisiensi usaha;8).Musyawarah untuk mufakat dalam pengambilan keputusan; 9).Kepekaan dan ketanggapan masyarakat terhadap masalah, kebutuhankebutuhan dan kepentingan-kepentingan umum masyarakat. Faktor yang mempengaruhi partisipasi masyarakat dalam suatu program juga dapat berasal dari unsur luar/lingkungan. Menurut Holil ada 4 poin yang dapat mempengaruhi partisipasi masyarakat yang berasal dari luar/lingkungan ${ }^{18}$, yaitu: 1). Komunikasi yang intensif antara sesama warga masyarakat, antara warga masyarakat dengan pimpinannya serta antara sistem sosial di dalam masyarakat dengan sistem di luarnya; 2). Iklim sosial, ekonomi, politik dan budaya, baik dalam kehidupan keluarga, pergaulan, permainan, sekolah maupun masyarakat dan bangsa yang menguntungkan bagi serta mendorong tumbuh dan berkembangnya partisipasi masyarakat; 3). Kesempatan untuk berpartisipasi. Keadaan lingkungan serta proses dan struktur sosial, sistem nilai dan norma-norma yang memungkinkan dan mendorong terjadinya partisipasi sosial; 4). Kebebasan untuk berprakarsa dan berkreasi. Lingkungan di dalam keluarga masyarakat atau lingkungan politik, sosial, budaya yang memungkinkan dan mendorong timbul dan berkembangnya prakarsa, gagasan, perseorangan atau kelompok.

\section{Pengertian Konservasi}

Konservasi itu sendiri merupakan berasal dari kata Conservation yang terdiri atas kata con (together) dan servare (keep/save) yang memiliki pengertian mengenai upaya memelihara apa yang kita punya (keep/save

\footnotetext{
${ }^{18}$ Ibid. Halaman 78
} 
what you have), namun secara bijaksana (wise use). Menurut Kamus Besar Bahasa Indonesia (KBBI) konservasi berarti (1) pemeliharaan dan perlindungan sesuatu secara teratur untuk mencegah kerusakan dan kemusnahan dng jalan mengawetkan; pengawetan; pelestarian; (2) proses menyaput bagian dalam badan mobil, kapal, dsb untuk mencegah karat. Ide ini dikemukakan oleh Theodore Roosevelt (1902) yang merupakan orang Amerika pertama yang mengemukakan tentang konsep konservasi. Konservasi dalam pengertian sekarang, sering diterjemahkan sebagai the wise use of nature resource (pemanfaatan sumberdaya alam secara bijaksana). Konservasi juga dapat dipandang dari segi ekonomi dan ekologi dimana konservasi dari segi ekonomi berarti mencoba mengalokasikan sumberdaya alam untuk sekarang, sedangkan dari segi ekologi, konservasi merupakan alokasi sumberdaya alam untuk sekarang dan masa yang akan datang. Apabila merujuk pada pengertiannya, konservasi didefinisikan dalam beberapa batasan, sebagai berikut : 1).Konservasi menurut American Dictionary adalah menggunakan sumberdaya alam untuk memenuhi keperluan manusia dalam jumlah yang besar dalam waktu yang lama; 2).Konservasi menurut Randall adalah alokasi sumberdaya alam antar waktu (generasi) yang optimal secara sosial ; 3).Konservasi menurut IUCN adalah merupakan manajemen udara, air, tanah, mineral ke organisme hidup termasuk manusia sehingga dapat dicapai kualitas kehidupan manusia yang meningkat termasuk dalam kegiatan manajemen adalah survai, penelitian, administrasi, preservasi, pendidikan, pemanfaatan dan latihan; 4).Konservasi menurut WCS adalah manajemen penggunaan biosfer oleh manusia sehingga dapat memberikan atau memenuhi keuntungan yang besar dan dapat diperbaharui untuk generasi-generasi yang akan datang. 
Menurut Anik Sarminingsih bahwa dalam pengelolaan sumberdaya air menganut tujuh azas seperti berikut ${ }^{19}$ :

1. Asas Kelestarian, mengandung pengertian bahwa pendayagunaan sumber daya air diselenggarakan dengan menjaga kelestarian fungsi sumber daya air secara berkelanjutan.

2. Asas Keseimbangan, mengandung pengertian untuk senantiasa menempatkan fungsi sosial, fungsi lingkungan hidup, dan fungsi ekonomi secara harmonis.

3. Asas Kemanfaatan Umum,mengandung pengertian bahwa pengelolaan sumber daya airdilaksanakan untuk memberikan manfaat sebesarbesarnya bagikepentingan umum secara efektif dan efisien.

4. Asas Keterpaduan dan Keserasian,mengandung pengertian bahwa pengelolaan sumber daya air dilakukansecara terpadu dalam mewujudkan keserasian untuk berbagai kepentingandengan memperhatikan sifat alami air yang dinamis.

5. Asas Keadilan, mengandung pengertianbahwa pengelolaan sumber daya air dilakukan secara merata ke seluruhlapisan masyarakat di wilayah tanah air sehingga setiap warga negara berhakmemperoleh kesempatan yang sama untuk berperan dan menikmati hasilnya secara nyata, dengan tetap memberikan perlindungan kepada lapisan masyarakat yang tingkat ekonominya berkekurangan.

6. Asas Kemandirian, mengandung pengertian bahwa pengelolaan sumber daya air dilakukan dengan memperhatikan kemampuan gan keunggular. norma dan sumber daya setempat.

7. Asas Transparansi dan Akuntabilitas, mengandung pengertian bahwa pengelolaan sumber daya air dilakukan secara terbuka dan bartanggungjawab.

${ }^{19}$ Anik Sarminingsih, Evaluasi Kekritisan Lahan Daerah Aliran Sungai (DAS) dan Mendesaknya Langkah-Langkah Konservasi Air, Jurnal PRESIPITASI Vol. 2 No.1 September 2007, Halaman 8-14 
Partisipasi masyarakat dalam mewujudkan Kuningan sebagai kabupaten konservasi merupakan hal sangat penting dalam mendukung programprogram pemerintah daerah, sehingga dengan terlaksananya programprogram tersebut maka tujuan pemerintah daerah kabupaten kuningan tercapai. Ada tiga aspek yang perlu di jelaskan terlebih dahulu dalam arikel ini pertama kata "Partsipasi" menurut Kamus Besar Bahasa Indonesia (KBBI) berarti, (1). Prihal turut berperan serta dalam suatu kegiatan; (2). Keikusertaan; dan (3) peran serta. Dengan demikian, berpartsipasi mengandung arti bahwa: (1) melakukan partisipasi; (2). Berperan serta (dalam suatu kegiatan); dan (3) ikut serta. Sebagai contoh kalimat yang didalamnya memuat kata "partisipasi" adalah: seluruh masyarakat harus berpartisipasi dalam menyukseskan pembangunan. Kedua, kata “ masyarakat" dalam Kamus Besar Bahasa Indonesia (KKBI) diartikan Definisi Masyarakat menurut Kamus Besar Bahasa Indonesia (KBBI) berarti "sejumlah manusia dl arti seluas-luasnya dan terikat oleh suatu kebudayaan yg mereka anggap sama". sedangkan "masyarakat" berakar dari bahasa Arab, musyarakah. Arti yang lebih luasnya, sebuah masyarakat adalah suatu jaringan hubungan-hubungan antar entitas-entitas. Masyarakat adalah sebuah kelompok atau komunitas yang interdependen atau individu yang saling bergantung antara yang satu dengan lainnya. Pada umumnya sebutan masyarakat dipakai untuk mengacu sekelompok individu yang hidup bersama dalam satu komunitas yang teratur. Syaikh Taqyuddin An-Nabhani seorang pakar sosiologi menjabarkan tentang definisi masyarakat, "sekelompok manusia bisa disebut sebagai suatu masyarakat apabila mempunyai pemikiran, perasaan, serta sistem atau aturan yang sama". ${ }^{20}$ Dengan kesamaan itu, manusia lalu berhubungan saling berinteraksi antara sesama mereka berdasarkan kepentingan bersama.

\footnotetext{
${ }^{20}$ Definisi masyarakat http://sosialsosiologi.blogspot.com/2012/12/definisi-masyarakat.html diakeses
} 10 Oktober 2013 
Menurut hipotesis peneliti partisipasi masyarakat khususnya dalam konservasi lingkungan harusnya tinggi karena berbeda dengan partisipasi politik dalam pilkada-pilkada yang cenderung turun karena kejenuhan masyarakat, penelitian ini akan menguji apakah masyarakat mempunyai partisipasi dalam melakukan kegiatan-kegiatan yang mendukung konservasi di kabupaten kuningan. Tujuan yang dilakukan dalam penelitian ini adalah untuk mengumpulkan data dan informasi tentang bagaimana “" Partisipasi masyarakat dalam mewujudkan Kuningan sebagai Kabupaten Konservasi" sesuai dengan amanat Peraturan Daerah Kabupaten Kuningan Nomor 12 Tahun 2007 tentang Konservasi Sumber Daya Air dan berdasarkan dari latar belakang dan pokok permasalahan di atas, maka tersusun yang menjadi tujuan penelitian ini adalah :

1. Untuk mengetahui bagaimana Implementasi Peraturan Daerah Kabupaten Kuningan Nomor 12 Tahun 2007 tentang Konservasi Sumber Daya Air.

2. Untuk mengetahui apa saja bentuk partisipasi masyarakat dalam mewujudkan Kuningan sebagai Kabupaten Konservasi.

Manfaat yang diharapkan dalam penelitian yang berjudul tentang "Partisipasi masyarakat dalam mewujudkan Kuningan sebagai Kabupaten Konservasi" sesuai dengan amanat Peraturan Daerah Kabupaten Kuningan Nomor 12 Tahun 2007 tentang Konservasi Sumber Daya Ai" adalah penelitian penelitian ini diharapkan dapat memberikan manfaat bagi berbagai pihak yang berminat maupun terkait dengan konservasi sumberdaya air antara lain yaitu :

1. Bagi peneliti, dapat menganalisis partisipasi masyarakat dalam mewujudkan kuningan menjadi kabupaten konservasi.

2. Bagi akademisi, penelitian ini dapat dijadikan sebagai sumber informasi atau referensi untuk penelitian selanjutnya.

3. Penelitian ini secara praktis adalah dapat di gunakan dalam pembuatan dan perbaikan kebijakan yang berkaitan dengan lingkungan hidup dan 
pengaturan dalam meningkatkan partisipasi masyarakat dalam mendukung pelestarian lingkungan hidup dan konservasi khususnya di Kabupaten Kuningan dan umumnya di Indonesia,

4. Penelitian ini mencoba memberikan gambaran tentang partisipasi masyarakat di kabupaten kuningan dalam mewujudkan kuningan sebagai kabupaten konservasi,

5. Hasil penelitian ini diharapkan dapat memberikan sumbangan pemikiran bagi pembaharuan khasanah keilmuan di bidang ilmu hukum pada umumnya terutama yang bekenaan dengan hukum lingkungan dan sosiologi hukum di Indonesia.

Partisipasi masyarakat merupakan hal yang sangat diperlukan dalam rangka mendukung kuningan sebagai kabupaten konservasi, Konservasi merupakan hal yang sensitif maka harus melibatkan masyarakat, pengelolaan lingkungan hidup tidak berguna apabila tidak mengikut sertakan masyarakat dan keikutsertaan masyarakat tanpa pengetahuan terhadap esensi pengelolaan lingkungan hidup meyebabkan pemborosan. Jadi , mengikutsertakan masyarakat yang mengerti prinsip kelestarian menjadikan pengelolaan lingkungan hidup efektif dan efisien ${ }^{21}$. Adapun program-program yang melibatkan masyarakat adalah sebagai berikut :

a. Program Seruling (siswa peduli lingkungan), Seruling adalah program yang mengikutsertakan siswa dalam melakukan konservasi lingkungan dengan cara menanam pohon di lingkungan sekolah sehingga lingkungan menjadi asri dan nyaman dalam kegiatan belajar mengajar adapun program ini diharuskan siswa baru membawa bibit pohon sebagai bentuk partisipasi siswa dalam mewujudkan kuningan sebagai kabupaten konservasi, program ini sudah dan terus berjalan dan terus berkembang meluas tidak saja kalangan siswa baru di kabupaten kuningan tapi sudah menularkan ke kalangan perguruan tinggi yaitu dengan adanya kegiatan

${ }^{21}$ Amiluhur Soeroso, Konservasi Lingkungan Kawasan Berbasis Manajemen Pembangunan Masyarakat, Jurnal Ekonomi Pembangunan Vol. 12 Nomor 1 April 2007, Halaman. 49-67. 
penanaman pohon olah para mahasiswa baru di lingkungan perguruan tinggi di kabupaten kuningan. Selain kegiatan penanaman pohon konservasi juga masuk kedalam kurikulum pendidikan yang ada di kabupaten kuningan. Program seruling dilakukan oleh beberapa sekolah yaitu seperti SMKN 1 Kuningan dengan melakukan penenanaman pohon di Kecamatan Cigugur dan SMA ITUS melakukan penanaman di lereng gunung cermai. Atas dukungan semua pihak piagam atau peghargaan telah diterima oleh Pemerintah Daerah Kuningan dalam bidang Koservasi Lingkungan yaitu Kalpataru yang diterima oleh Bupati Kuningan dalam rangka Bupati pembina lingkungan hidup dan juga kuningan mendapat piala Adipura sebagai penghargaan dalam bidang lingkungan dari Kementerian Lingkungan Hidup dan Sejumlah prestasi lain terkait pelestarian lingkungan juga banyak diraih Kabupaten Kuningan seperti anugerah Adiwiyata yang diraih SMPN 1 Pasawahan dan SMPN 2 Pasawahan sebagai sekolah berwawasan lingkungan.

b. Program Aparat peduli lingkungan( Apel), Apel adalah program yang menyentuh kalangan aparatur pemerintah di kabupaten kuningan yaitu dengan kegiatan penanaman pohon yang berkaitan dengan kenaikan pangkat serta hari bumi dan hari besar lainnya, dalam program ini setiap pegawai atau aparatur di pemerintah daerah yang naik pangkat harus menyediakan dan menanam pohon di wilayah yang sudah di tentukan tentunya ini merupakan kegiatan yang sangat baik dalam mendukung program pemerintah daerah.

c. Program pemberdayaan Pengantin peduli lingkungan (Pepeling), Pepeling adalah program kerjasama dengan Kementrian Agama Republik Indonesia khususnya adalah Kantor Urusan Agama dengan Pemerintah Daerah Kabupaten Kuningan dalam rangka pelestarian lingkungan hidup, program ini dilaksanakan di setiap kecamatan di Kabupaten Kuningan dalam program ini setiap calon pengantin yang akan menikah diharuskan memberikan 10 bibit pohon yang diserahkan dan akan ditanam oleh dinas 
teknis yang membidangi lingkungan hidup tujuan dari program ini adalah yaitu supaya masyarakat belajar tentang bagaimana berpartisipasi menjaga lingkungan hidup agar lestari demi anak dan cucunya nanti.

\section{Kesimpulan}

Partisipasi Masyarakat dalam mewujudkan Kuningan sebagai Kabupaten Konservasi lokasi penelitian yaitu dilakukan di Kabupaten Kuningan. Tujuan penelitian ini adalah untuk mengetahui Implementasi Peraturan Daerah Kabupaten Kuningan Nomor 12 Tahun 2007 tentang Konservasi Sumber Daya Air. Berdasarkan uraian diatas untuk mencapai tujuan konservasi di kabupaten kuningan maka pemerintah daerah kabupaten kuningan melakukan upaya-upaya dalam hal kebijakan yaitu dengan membuat peraturan-peraturan yang berkaitan dan yang mendukung konservasi, Selain membuat kebijakan-kebijakan yang berkaitan dengan lingkungan kabupaten kuningan juga meningkatkan status Hutan Lindung Gunung Cermai menjadi Taman Nasional Gunung Cermai, membuat Hutan Kota dan membuat Waduk atau Embung di berbagai wilayah dan Untuk mengetahui apa partisipasi masyarakat dalam mewujudkan Kuningan sebagai Kabupaten Konservasi. Penelitian ini dapat dapat berguna antara lain yaitu Penelitian ini secara praktis adalah dapat di gunakan dalam pembuatan kebijakan yang berkaitan dengan lingkungan hidup dan pengaturan dalam meningkatkan partisipasi masyarakat dalam mendukung pelestarian lingkungan hidup dan konservasi khususnya di Kabupaten Kuningan dan umumnya di Indonesia. Metode penelitian yang digunakan oleh peneliti dalam pembahasan penelitian ini adalah metode evaluatif analisis, yaitu suatu metode mengumpulkan dan menyajikan data yang diperoleh untuk menganalisis keadaan yang sebenarnya dan selanjutnya dilakukan analisa rasional berdasarkan acuan yuridis melalui penelitian kepustakaan dan penelitian lapangan. Hasil penelitian yaitu partisipasi masyarakat dalam mewujudkan kuningan sebagai kabupaten konservasi merupakan langkah yang maju karena turut serta dalam program pemerintah dalam membantu perlindungan dan 
pemeliharaan lingkungan hidup sehingga akan tercipta lingkungan yang asri dan sehat. Bentuk partisipasi masyarakat kabupaten kuningan yaitu melalui program pengantin peduli lingkungan (pepeling), siswa peduli lingkungan (seruling) dan aparatur peduli lingkungan (apel).

\section{Daftar Pustaka}

Anik Sarminingsih, Evaluasi Kekritisan Lahan Daerah Aliran Sungai (DAS) dan Mendesaknya Langkah-Langkah Konservasi Air, Jurnal PRESIPITASI Vol. 2 No. 1 Septemberr 2007.

Ach. Wazir Ws., et al., ed. Panduan Penguatan Menejemen Lembaga Swadaya Masyarakat. Jakarta: Sekretariat Bina Desa dengan dukungan AusAID melalui Indonesia HIV/AIDS and STD Prevention and Care Project, 1999.

Holil Soelaiman. Partisipasi Sosial dalam Usaha Kesejahteraan Sosial. Bandung : STKS, 1980

Isbandi Rukminto Adi. Perencanaan Partisipatoris Berbasis Aset Komunitas: dari Pemikiran Menuju Penerapan. Depok: FISIP UI Press., 2007.

Linda Donarika Marbun, Partisipasi Masyarakat dalam Pemeliharaan prasarana pasca program NUSSP di Kelurahan Sumur Pacing dan Manis Jaya Kota Tanggerang, Semarang: Tesis Undip, 2010.

Nana Sudiana dan Hasmana Soewandita, Pola Konservasi Sumber Daya Air di Daerah Aliran Sungai Siak, Jurnal Alami Vol. 12 Nomor 1 Tahun 2007.

Siti Kotijah, Implementasi Prinsip-prinsip Kehutanan dalam Rangka Konservasi Kehutanan: studi kasus di Jawa Timur, Jurnal Magister Hukum, Vol. 1 Nomor 2, Surabaya : Program Studi Magister Ilmu Hukum, Universitas Wisnuwardhana, 2010.

Soerjono Soekanto, Ringkasan metode Penelitian Hukum Empiris, Jakarta:Ind-Hill ,1990.

Press, 1984.

Pengantar Penelitian Hukum.cet.2007, Jakarta : UI 
Jurnal Unifikasi, ISSN 2354-5976

Vol. 2 No. 1 Januari 2015

Suwari Akhmaddhian, "Peran Pemerintah Daerah dalam Mewujudkan Hutan Konservasi Berdasarkan Undang-Undang Nomor 41 Tahun 1999 Tentang Kehutanan (Studi di Kabupaten Kuningan)." Jurnal Dinamika Hukum Vol. 13,Nno. 3 September 2013, Purwokerto : FH Unsoed.

http://majidbsz.wordpress.com/2008/06/30/pengertian-masyarakat diakes tanggal 09 Oktober 2013

http://sosialsosiologi.blogspot.com/2012/12/definisi-masyarakat.html diakses tanggal 10 Okteber 2013 